\title{
Smoking and COVID-19
}

\section{Sigara İcmek ve COVID-19}

Kadir Canoğlu, Tayfun Caliskan, Zafer Kartaloğlu

\section{Abstract}

It is known that SARS-CoV-2 affects the respiratory tract and causes pneumonia and respiratory failure in patients. Smoking increases susceptibility to many respiratory diseases, including infections, and affects the prognosis and mortality of these diseases. The increased levels of angiotensin converting enzyme-2, which is a binding receptor for SARS-CoV-2 in the lungs, suggest that smoking has negative effects on patients with COVID-19. In this review, the relationship between smoking and COVID-19 is examined with a review of current literature.

Key words: Smoking, COVID-19, pandemic, pneumonia.

\section{Özet}

SARS-CoV-2'nin solunum yollarını etkilediği ve hastalarda pnömoni ve solunum yetmezliğine neden olduğu bilinmektedir. Sigara içmek enfeksiyonlar dahil birçok solunum yolu hastalığına yatkınlığı artırmakta ve bu hastalıkların prognozunu ve ölüm oranını etkilemektedir. Akciğerlerde SARS-CoV-2 için bağlanma yeri olduğu bildirilen anjiyotensin dönüştürücü enzim2'nin artan seviyeleri, sigaranın COVID-19 hastalığı üzerinde olumsuz etkileri olduğunu düşündürmektedir. Bu derlemede, sigara ve COVID-19 arasındaki ilişki, mevcut literatürle birlikte incelenmiştir.

Anahtar Sözcükler: Sigara içme, COVID-19, pandemi, pnömoni.

Department of Pulmonology, Health Sciences University, Sultan 2. Sağlık Bilimleri Üniversitesi, Sultan 2. Abdülhamid Han Eğitim Abdulhamid Han Training and Research Hospital, İstanbul, Turkey ve Araştırma Hastanesi, Göğüs Hastalıkları Servisi, İstanbul

Submitted (Başvuru tarihi): 13.12.2020 Accepted (Kabul tarihi): 14.01.2021

Correspondence (iletişim): Kadir Canoğlu, Department of Chest Disease, Department of Pulmonology, Health Sciences University, Sultan 2. Abdulhamid Han Training and Research Hospital, İstanbul, Turkey

e-mail: kadircano@gmail.com 
More than 1.4 million people have died due to COVID19 worldwide since December 2019, when the first case was reported (1). In just 8 months, many scientific articles related to the disease have been published, and the epidemiological, clinical, laboratory and radiological findings of the disease have been described. The disease is known to be transmitted through the respiratory tract, and pneumonia is detected in approximately $5-10 \%$ of patients with COVID-19. Those with advanced forms of the disease require intensive care, and patients develop acute respiratory distress syndrome. Mortality is generally related to respiratory failure and the development of sepsis in intensive care $(2,3)$.

Smoking increases the frequency of many malignant and benign lung diseases, and is the most known proven cause of lung cancer (4). In addition, interstitial lung diseases such as idiopathic pulmonary fibrosis, histiocytosis $X$, desquamative interstitial pneumonia, respiratory bronchiolitis associated interstitial lung disease, and acute eosinophilic pneumonia are more common in smokers $(5,6)$. Epidemiological studies have stated that the risk of upper and lower respiratory tract infections is high in smokers. The proinflammatory properties of smoking are well known, including the increased production of proinflammatory cytokines such as tumor necrosis factoralpha (TNF- $\alpha$ ), interleukin-1 (IL-1), interleukin-6 (IL-6), interleukin-8 (IL-8) and granulocyte-macrophage colonystimulating factor (GM-CSF), and an increased the accumulation of immune cells in the airway. Due to the complex nature of the immune system, however, it is difficult to predict the nature of the total immune response to microbial agents, given that non-affected defense mechanisms may compensate for the affected areas (7-9). Smoking also increases the development of tuberculosis. Altet et al. (10) found that passive smoking, which is correlated also with urine cotinine levels, increased the risk of active tuberculosis by approximately 5 times in a prospective study (11). Since COVID-19 affects primarily the respiratory system, studies tend to focus on chronic respiratory diseases, such as chronic obstructive pulmonary disease (COPD) and smoking in patients with COVID-19. That said, studies comparing smoking rates in patients with COVID-19 have reported different results in terms of those in need of intensive care, and those succumbing to the disease, among others.

In this review, we investigate the different smoking rates of patients treated for COVID-19, and ascertain whether or not the disease is more severe in smokers.

\section{Pathogenesis}

Angiotensin converting enzyme 2 (ACE-2) is a type I transmembrane metallocarboxypeptidase that was first identified two decades ago, and breaks down angiotensin II to and angiotensin- (1-7). ACE-2 is present in the respiratory system, heart and gastrointestinal system $(12,13)$. Leung MJ et al. (14) obtained cytological brushing samples from smoking patients, and made COPD diagnoses via a bronchoscopy approach, and also examined the ACE-2 expression in the resected lung tissue. The study included 10 smoking patients with COPD, nine nonsmoking controls and eight healthy smokers. The ACE-2 gene was expressed significantly higher in smokers than in non-smokers.

Higher ACE-2 levels in active smokers and in patients with COPD may partially explain the severe COVID-19 increase in this population. Smoking cessation and the close follow-up of these groups are very important in COVID-19 prevention, and early diagnoses are emphasized in this patient group.

SARS-CoV-2 has type- 1 transmembrane spike (S) glycoproteins that contains two different functional proteins $(\mathrm{S} 1$ and S2) regulating entry into the host cell by the virus. The S1 subunit binds to the ACE-2 receptor (15), and the airway epithelium is the main entry point for COVID-19 into the body. ACE-2 is the experimentally validated SARS-CoV-2 receptor (16). The S protein of SARS-CoV-2 has a significantly higher affinity for ACE-2 and its binding rate is higher than for SARS-CoV $(17,18)$. Type-2 pneumocytes express the ACE-2 protein (19). Since ACE2 is a binding site for COVID-19, it may be considered a target for therapies to be developed for its treatment.

Cai $G$ et al. (20) reported a $25 \%$ increase in pulmonary ACE-2 expression in smokers, which may indicate that smokers are at higher risk of COVID-19 infection than non-smokers. That said, there are also studies making conflicting claims. Changeux JP et al. (21) argued that active smoking may protect against COVID-19, suggesting that the nicotinic acetylcholine receptor (nAChR) plays an important role in the development of COVID-19 infection. According to this hypothesis, the virus enters the body through the olfactory system neurons and/or lungs rather than the ACE-2 receptors in the lungs. nAChR is present in the lung epithelium, and may be the binding receptor in the lungs when the virus enters the body. 
Table 1: The studies about Smoking and COVID-19

\begin{tabular}{|c|c|c|c|c|c|}
\hline Study & Study & Study design & Comparison & Smoking Rate & Outcomes \\
\hline $\begin{array}{l}\text { Zhou F, et } \\
\text { al. (22) }\end{array}$ & $\begin{array}{l}\text { n: } 191 \text { adult inpa- } \\
\text { tients } \\
\text { (aged } \geq 18 \text { years) } \\
\text { with laboratory } \\
\text { confirmed } \\
\text { COVID-19 }\end{array}$ & $\begin{array}{l}\text { A retrospective } \\
\text { cohort study }\end{array}$ & Yes & $\begin{array}{l}\text { Current smokers: } n=11(6 \%), \\
\text { - Non-survivors (n: } 54): n=5(9 \%) \\
\text { - Survivors }(n: 137): n=6(4 \%) \\
(p=0.21)\end{array}$ & $\begin{array}{l}54 \text { patients died during hospitalization and } 137 \text { were } \\
\text { discharged. No statistically significant difference be- } \\
\text { tween the smoking rates of survivors and non-survivors } \\
(p=0.21 \text { ) with regard to mortality from COVID-19. }\end{array}$ \\
\hline $\begin{array}{l}\text { Zhang JJ, } \\
\text { et al. (23) }\end{array}$ & $\begin{array}{l}\text { n: } 140 \text { hospitalized } \\
\text { patients with SARS- } \\
\text { CoV-2 }\end{array}$ & $\begin{array}{l}\text { A retrospective } \\
\text { study }\end{array}$ & Yes & $\begin{array}{l}\text { Non-severe patients: }(n=82) \\
\text { - Former smokers: } n=3(3.7 \%) \\
\text { - Current smokers: } n=0 \\
\text { Severe patients: }(n=58) \\
\text { - Former smokers: } n=4(6.9 \%) \\
\text { - Current smokers: } n=2(3.4 \%) \\
(p=0.448 \text { and } 0,170)\end{array}$ & $\begin{array}{l}\text { Low prevalence of smokers and no allergic diseases } \\
\text { despite of drug hypersensitivity and urticaria was self- } \\
\text { reported by any patients, indicating that allergic diseas- } \\
\text { es and smoking history may not be the susceptible } \\
\text { factors for COVID-19 }\end{array}$ \\
\hline $\begin{array}{l}\text { Huang C, } \\
\text { et al. (24) }\end{array}$ & $\begin{array}{l}\text { n: } 41 \text { Laboratory } \\
\text { confirmed 2019- } \\
\text { nCoV patients, } \\
\text { n:13 needed to be } \\
\text { admitted to the ICU }\end{array}$ & $\begin{array}{l}\text { A prospective } \\
\text { study }\end{array}$ & Yes & $\begin{array}{l}\text { Current smokers: } n=3 \\
\quad \quad \text { ICU care }(n: 13): n=0 \\
\text { - Non-ICU care }(n: 28): n=3(11 \%) \\
\text { Current smokers in ICU care vs non-ICU care patients } \\
(p=0.31)\end{array}$ & $\begin{array}{l}28(68 \%) \text { of } 41 \text { patients were discharged and } 6(15 \%) \\
\text { patients died. }\end{array}$ \\
\hline $\begin{array}{l}\text { Guan WJ, } \\
\text { et al. (25) }\end{array}$ & $\begin{array}{l}\mathrm{n}: 1099 \text { Patients } \\
\text { with Laboratory } \\
\text { confirmed } \\
\text { COVID-19 }\end{array}$ & $\begin{array}{l}\text { A retrospective } \\
\text { study }\end{array}$ & No & 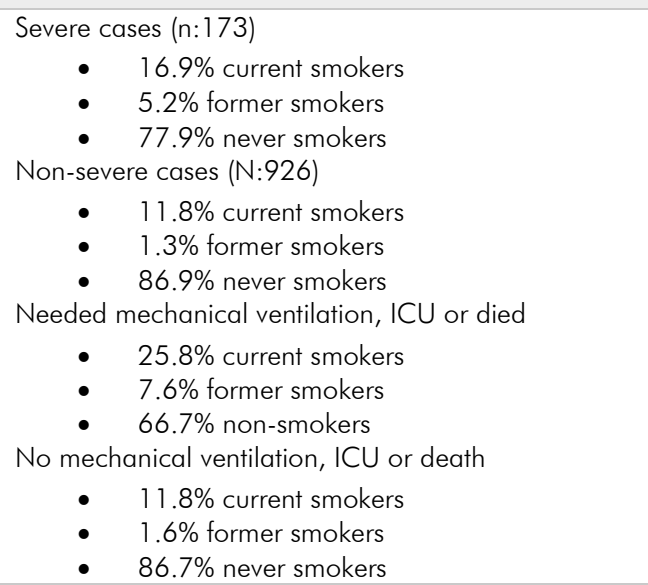 & $\begin{array}{l}\text { No statistical analysis for evaluating the association } \\
\text { between the severity of the disease outcome and smok- } \\
\text { ing status was conducted. }\end{array}$ \\
\hline $\begin{array}{l}\text { Liu W, et } \\
\text { al. (26) }\end{array}$ & $\begin{array}{l}\text { n: } 78 \text { Patients } \\
\text { tested positive for } \\
\text { COVID-19 }\end{array}$ & $\begin{array}{l}\text { A retrospective } \\
\text { multicenter } \\
\text { cohort study }\end{array}$ & Yes & $\begin{array}{l}\text { Progression Group ( } \mathrm{n}: 11) \\
\text { - } \mathrm{n}: 3(27.3 \%) \text { smokers } \\
\text { Improvement/stabilization group ( } \mathrm{N}: 67) \\
\text { - } \mathrm{n}: 2(3 \%) \text { smokers }\end{array}$ & $\begin{array}{l}\text { Progression group } \\
\bullet \quad \mathrm{n}: 11(14.1 \%) \\
\text { Improvement/stabilization group } \\
\bullet \quad \mathrm{n}: 67 \text { (85.9\%) }\end{array}$ \\
\hline
\end{tabular}




\begin{tabular}{|c|c|c|c|c|c|}
\hline & & & & $\begin{array}{l}\text { Multivariate logistic regression analysis indicated that the history of } \\
\text { smoking was a risk factor of disease progression } \\
(\mathrm{OR}=14.285 ; 95 \% \mathrm{Cl}: 1.577-25.000 ; \mathrm{p}=0.018)\end{array}$ & $\begin{array}{l}\text { Several factors that led to the progression of COVID-19 } \\
\text { pneumonia were identified, including age, history of } \\
\text { smoking, maximum body temperature at admission, } \\
\text { respiratory failure, albumin, C-reactive protein. }\end{array}$ \\
\hline $\begin{array}{l}\text { Yang } X \text {, et } \\
\text { al. (27) }\end{array}$ & $\begin{array}{l}\text { n: } 52 \text { critically ill } \\
\text { adult patients with } \\
\text { SARS-CoV-2 pneu- } \\
\text { monia who were } \\
\text { admitted to ICU }\end{array}$ & $\begin{array}{l}\text { A single cen- } \\
\text { tered, retro- } \\
\text { spective, obser- } \\
\text { vational study }\end{array}$ & No & $\begin{array}{l}\text { Smoking: } \\
\text { - Survivors (n: 20): N: } 2 \text { (10\%) } \\
\text { - Non-survivors (n: } 32): \text { n: } 0 \\
\quad \text { All patients: } \mathrm{n:} 2(4 \%)\end{array}$ & $\begin{array}{l}\text { Compared with survivors, non-survivors were older } \\
(64 \cdot 6 \text { years vs } 51 \cdot 9 \text { years), more likely to develop ARDS } \\
(26 \text { [81\%] patients vs } 9 \text { [45\%] patients), and more likely } \\
\text { to receive mechanical ventilation ( } 30 \text { [94\%] patients vs } \\
7 \text { [35\%] patients), either invasively or non-invasively. } \\
\text { Most patients had organ function damage, including } 35 \\
(67 \%) \text { with ARDS, } 15(29 \%) \text { with acute kidney injury, } 12 \\
(23 \%) \text { with cardiac injury, } 15 \text { (29\%) with liver dysfunc- } \\
\text { tion, and one (2\%) with pneumothorax. } 37 \text { (71\%) pa- } \\
\text { tients required mechanical ventilation. Hospital- } \\
\text { acquired infection occurred in seven (13.5\%) patients }\end{array}$ \\
\hline $\begin{array}{l}\text { Guan WJ, } \\
\text { et al. (28) }\end{array}$ & $\begin{array}{l}\text { n: } 1590 \text { laboratory } \\
\text { confirmed hospital- } \\
\text { ized patients with } \\
\text { COVID-19 }\end{array}$ & $\begin{array}{l}\text { A retrospective } \\
\text { case study }\end{array}$ & No & $\begin{array}{l}\text { Former/current smokers: } \\
\text { - Total: } \mathrm{n}: 111(7 \%) \\
\text { - No comorbidity: } \mathrm{n:} 64 \text { (5.4\%) } \\
\text { - Having comorbidity: n: } 47 \text { (11.8\%) }\end{array}$ & $\begin{array}{l}\text { After adjusting for age and smoking status, patients with } \\
\text { COPD ( } \mathrm{HR} 2.68,95 \% \mathrm{Cl} 1.42-5.05) \text {, diabetes (HR } \\
1.59,95 \% \mathrm{Cl} 1.03-2.45) \text {, hypertension (HR } 1.58 \\
95 \% \mathrm{Cl} 1.07-2.32 \text { ) and malignancy ( } \mathrm{HR} 3.50,95 \% \mathrm{Cl} \\
\text { 1.60-7.64) were more likely to reach to the composite } \\
\text { endpoints than those without. }\end{array}$ \\
\hline $\begin{array}{l}\text { Wang } R \text {, et } \\
\text { al. (29) }\end{array}$ & $\begin{array}{l}\mathrm{n}: 125 \text { hospitalized } \\
\text { patients with } \\
\text { COVID-19 }\end{array}$ & $\begin{array}{l}\text { A retrospective } \\
\text { descriptive } \\
\text { study }\end{array}$ & Yes & $\begin{array}{l}\mathrm{n:} 16 \text { (12.8\%) of them have a history of smoking. } \\
\text { - Critical patients ( } \mathrm{n}: 25): 7 \text { (28\%) } \\
\text { P value: } 0.027\end{array}$ & $\begin{array}{l}\text { Old age, chronic underlying diseases and smoking } \\
\text { history may be risk factors to worse condition. }\end{array}$ \\
\hline $\begin{array}{l}\text { Miyara M, } \\
\text { et al. (30) }\end{array}$ & $\begin{array}{l}\mathrm{n}: 482 \text { COVID-19 } \\
\text { patients ( } \mathrm{n}: 139 \\
\text { outpatients and } \mathrm{n} \text { : } \\
343 \text { inpatients) }\end{array}$ & $\begin{array}{l}\text { A cross- } \\
\text { sectional survey }\end{array}$ & Yes & $\begin{array}{l}\text { Inpatient group: } \\
\text { - Rate of daily smoking: } 4.4 \% \text { ( } 5.4 \% \text { of men and } 2.9 \% \text { of wom- } \\
\text { en) } \\
\text { Outpatient group: } \\
\text { - Rate of daily smoking: } 5.3 \% \text { ( } 5.1 \% \text { of men and } 5.5 \% \text { of wom- } \\
\text { en) } \\
\text { The daily smokers rate in French population: } 25.4 \% \\
\text { The rate of current daily smokers was significantly lower in COVID- } 19 \\
\text { outpatients and inpatients ( } 80.3 \% \text { and } 75.4 \% \text {, respectively), as compared } \\
\text { to that in the French general population with standardized incidence } \\
\text { ratios according to sex and age of } 0.197[0.094-0.41] \text { and } 0.246 \\
{[0.148-0.408] \text {. These ratios did not significantly differ between the two }} \\
\text { groups }(P=0.63) \text {. }\end{array}$ & $\begin{array}{l}\text { The study highlights for the first time a dramatic de- } \\
\text { creased prevalence of daily current smokers both in } \\
\text { COVID-19 outpatients and inpatients as compared to } \\
\text { the general population. }\end{array}$ \\
\hline
\end{tabular}




\section{Scientific Articles}

Most scientific articles investigating the associations between smoking and COVID-19 are of Chinese origin, with fewer studies from other countries. The clinical course and risk factors related to mortality in hospitalized adult patients with COVID-19 were examined in a retrospective multicenter cohort study by Zhou $\mathrm{F}$ et al. (22) (Table 1). Of the 191 patients included in the study, 137 recovered and 54 died while hospitalized, with smoking rates of $4 \%(n=6)$ and $9 \%(n=5)$, respectively, but the difference was not statistically significant ( $p=0.21$ ). Smoking was not found to be statistically associated with mortality in a univariate analysis (Odds ratio $(O R)=2.23$, 95\% Confidence interval $(\mathrm{Cl})$ : 0.65-7.63, $p=0.20$ ), although only a small number of patients were enrolled in the study.

Zhang JJ et al. (23) made a retrospective analysis of the clinical features of 140 patients hospitalized with COVID19. Severe COVID-19 was defined based on the presence of such criteria as respiratory rate $\geq 30 / \mathrm{min}$, resting $\mathrm{SpO}_{2} \leq 93 \%$ or oxygenation index $\left(\mathrm{PaO}_{2} / \mathrm{FiO}_{2}\right) \leq 300$ $\mathrm{mmHg}$ in room air.

Only nine of the 140 patients were smokers, including both active and former smokers, of which seven quit smoking and two were current smokers. While four (6.9\%) of the seven patients who quit smoking were diagnosed with severe COVID-19, severe COVID-19 was diagnosed in only two patients (3.4\%) who were current smokers. The study found that smoking was not related with COVID-19 severity $(p=0.448$ and $p=0.170)$. In addition, when patients with a smoking index (daily number of cigarettes smoked $\times$ year) of $<400$ and those with $\geqslant$ 400 were compared, no significant difference was noted between the cumulative effect of smoking and the severity of the disease $(p>0.999)$. In the present study, it was found that although it seemed that smokers were less susceptible to COVID-19, the values did not reach a statistically significant level, and COVID-19 may be more severe in smokers (23).

The clinical features of 41 patients who were hospitalized with COVID-19 were prospectively investigated by Huang $C$ et al. (24) in two groups, being those treated in the intensive care unit (ICU) $(n=13)$ and those who were not treated in the ICU $(n=28)$, and the clinical parameters of the two groups were compared. Active smoking was identified in $0 \%$ of those treated in the ICU and in $11 \%(n=3)$ in those treated in the clinic, with no statistically significant difference $(p=0.31)$. In total, 68 percent $(28 / 41)$ of the patients recovered and 15 percent $(6 / 41)$ died. Due to the limited number of smoking patients, no conclusion was made suggesting a link between smoking and the need for ICU admission.

Guan WJ et al. (25) made a retrospective analysis of the clinical characteristics of 1,099 patients, including both inpatients and outpatients, being treated for COVID-19. The primary endpoints of the study were ICU need, invasive mechanical ventilation use or death. At the time of hospital admission, 926 of the patients were determined as non-severe and 173 as severe COVID-19. The rate of patients with primary endpoints was $6.1 \%(n=67)$. Under the never smoker, former smoker and current smoker classifications, smoking rates were $86.9 \%$ (793/913), $1.3 \%(12 / 913)$ and $11.8 \%(108 / 913)$ respectively in non-severe COVID-19 patients; $77.9 \%$ (134/172), 5.2\% $(9 / 172)$ and $16.9 \%(29 / 172)$ in patients with severe forms of the disease; and $66.7 \%(44 / 66), 7.6 \%(5 / 66)$ and $25.8 \%(17 / 66)$ in those with primary endpoints and $86.7 \%(883 / 1019), \quad 1.6 \% \quad(16 / 1019)$ and $11.8 \%$ $(120 / 1019)$ in those without primary endpoints, respectively. No statistical comparison was made of the groups in the study, although the rate of smoking (previous or active) was noted to be higher in those with severe COVID-19. In addition, the rate of smoking (previous or active) was also higher in patients with a primary endpoint, including the need intensive care, mechanical ventilation or death. This study suggests that smoking patients may be more susceptible to severe COVID-19.

The factors associated with the course of COVID-19 in 78 patients treated in hospital were examined in the multicenter retrospective cohort study conducted by Liu $\mathrm{W}$ et al. (26). Possible factors causing the worsening of COVID-19 pneumonia were investigated in the progression $(n=11)$ and recovery/stabilization $(n=67)$ groups in the study. A history of smoking was identified in $27.3 \%$ $(n=3)$ of the progression group and in $3 \%(n=2)$ of the recovery/stabilization group, with similar results in the two groups $(p=0.018)$. Smoking was found to be a risk factor for COVID- 19 progression in a multivariate logistic regression analysis $(O R=14.285 ; 95 \% \mathrm{Cl}: 1.577-$ $25.000 ; p=0.018)$, and it was further concluded that older age, higher body temperature, presence of respiratory failure at presentation, lower serum albumin and higher C-reactive protein levels were risk factors for COVID-19 pneumonia progression.

Yang et al. (27) investigated the clinical course and outcomes of 52 critically ill patients with COVID-19 pneumonia in a single-center, retrospective observational study, in which critically ill patients were defined as those 
who were mechanically ventilated in the ICU or who needed oxygen supplementation of $\mathrm{FiO}_{2} \geqslant 60 \%$. The primary outcomes of the study were the 28-day mortality rates after admission to the ICU, and the secondary outcomes were the incidence of patients with COVID-19 and acute respiratory distress syndrome (ARDS), and the ratio of patients requiring mechanical ventilation. Analysis included two groups, being survivors $(n=20)$ and nonsurvivors $(n=32)$. Smoking was identified in $10 \%(n=2)$ of the survivors and in $0 \%$ of those who died. No statistical comparison was made related to smoking, as the authors believed a meaningful interpretation may would not be possible due to the low number of cases and the low number of smoking patients.

Comorbidities and their effects on the disease were retrospectively analyzed by Guan et al. (28) in a study of 1,590 patients with COVID-19. The primary composite endpoints were admission to ICU and the need for invasive mechanical ventilation or mortality, with the risk of each compared in terms of the number or presence of comorbidities. The total smoking rate (former/current) in the study was $7 \%(111 / 1,590)$, and the smoking rate (previous/active) was $5.4 \%(n=64 / 1,191)$ in those without comorbidities (previous/active) and $11.8 \%$ ( $\mathrm{n}=$ $47 / 399$ ) in those with comorbidities. It is known that age and smoking are risk factors for comorbidities even in the general population, and so it was suggested in this study that the presence of COPD, diabetes mellitus, hypertension and malignancy may cause a poor prognosis after adjusting for age and smoking in a hazard regression model. In this study, it did not seem possible to establish a relationship between smoking and the course of COVID-19.

Wang et al. (29) made a retrospective analysis of the clinical and epidemiological characteristics of 125 patients hospitalized with COVID-19. Among the 25 critically ill patients, the rate of active smoking was $28 \%(n=7)$, and the rate of active smoking in non-critical patients was $9 \%(n=9)$, and the difference was statistically significant $(p=0.027)$. The authors concluded that older age, the presence of an underlying disease and smoking may be risk factors for a worsening course of COVID-19.

Miyara et al. (30) made a cross-sectional investigation of the relationship between smoking and susceptibility to COVID-19 in symptomatic patients treated for COVID-19 either as inpatients $(n=343)$ or outpatients $(n=139)$. The smoking rate was $4.4 \%$ among the inpatients $(5.4 \%$ in males; $2.9 \%$ in females) and $5.3 \%$ among the outpatients $(5.1 \%$ in males; $5.5 \%$ in females). While the mean smoking rate was $25.4 \%$ (28.2\% for males; $22.9 \%$ for females) in the French population, the smoking rates were similar between the outpatients and inpatients. It was concluded in the study that the contribution of daily smoking to the risk of development of symptomatic COVID-19 was very low when compared to the general population, although such a stated finding may be inappropriate due to the small sample size. Furthermore, the criteria for hospitalization/outpatient treatment were not clearly stated in the study, with groups established based on such subjective criteria as severe/non-severe symptoms, and so it would not really be appropriate to speak of a link between smoking and disease severity of the disease based on the available data.

There have been three systematic reviews and/or metaanalyses related to smoking and COVID-19. Zhao et al. (31) examined the effect of smoking and COPD on the severity of COVID-19, involving 11 case series in their review, and reported a pooled odds ratio of 4.38 (95\% $\mathrm{Cl}$ : 2.34-8.20) for COPD and 1.98 (95\% Cl: 1.29-3.05) for smoking for severe COVID-19 development. One study in particular affected the results, and it was reported that smoking history was not associated with COVID-19 severity in a subgroup analysis after this study was excluded. The reasons for this were interpreted as the exclusion of the study, which involved a large number of patients, and the lack of discrimination made between active and former smokers in other studies. It has been stated that a history of COPD and smoking contributes to the progression and worsening of COVID-19 (31).

Vardavas et al. (32) carried out a systematic review of smoking and COVID-19 in their analysis of five studies, and found the symptoms of severe COVID-19 to be 1.4times greater (Relative risk (RR) $=1.4,95 \% \mathrm{Cl}$ : 0.98 2.00) and the need for ICU and mechanical ventilation or mortality to be 2.4 -times greater $(\mathrm{RR}=2.4,95 \% \mathrm{Cl}$ : 1.43-4.04) in smokers than in non-smokers. The authors concluded that smoking may be associated with COVID19 severity and adverse outcomes.

Comorbidities in inpatients with COVID-19 were investigated by Emami et al. (33) in a meta-analysis of 10 previous studies. The prevalence of smoking was calculated as $7.63 \%$ of patients, while hypertension, cardiovascular diseases, diabetes mellitus, COPD, malignancy and chronic kidney disease were identified the most common comorbid diseases. The authors made no comment on the relationship between COVID-19 severity and smoking, but said that patients with underlying diseases were common among those with COVID-19, and such people 
should avoid close contact with other members of the community.

\section{CONCLUSION}

Smoking may affect the risk of contracting COVID-19, and may also influence the severity and mortality associated with the disease. Different results have been reported in studies examining smoking and COVID-19 that may be attributable to the relatively low number of COVID-19 cases and smokers in the studies. Furthermore, the workload of health systems during the COVID-19 pandemic, deficiencies in the registration system and the retrospective nature of the studies may also influence the findings. In conclusion, smoking increases the severity and mortality of COVID-19, especially in hospitalized patients, and so during the ongoing COVID-19 pandemic in particular, more attention should be paid to smoking cessation approaches, and patients should advised accordingly.

\section{CONFLICTS OF INTEREST}

None declared.

\section{AUTHOR CONTRIBUTIONS}

Concept - K.C., T.C., Z.K.; Planning and Design - K.C., T.C., Z.K.; Supervision - K.C., T.C., Z.K.; Funding - K.C., T.C., Z.K.; Materials - T.C., K.C.; Data Collection and/or Processing - T.C., K.C.; Analysis and/or Interpretation K.C., T.C., Z.K.; Literature Review - K.C., T.C., Z.K.; Writing - K.C., T.C., Z.K.; Critical Review - T.C., Z.K.

\section{YAZAR KATKILARI}

Fikir - K.C., T.C., Z.K.; Tasarım ve Dizayn - K.C., T.C., Z.K.; Denetleme - K.C., T.C., Z.K.; Kaynaklar - K.C., T.C., Z.K.; Malzemeler - T.C., K.C.; Veri Toplama ve/veya İşleme - T.C., K.C.; Analiz ve/veya Yorum - K.C., T.C., Z.K.; Literatür Taraması - K.C., T.C., Z.K.; Yazıyı Yazan - K.C., T.C., Z.K.; Eleştirel İnceleme - T.C., Z.K.

\section{REFERENCES}

1. World Health Organization. WHO Coronavirus Disease (COVID-19) Dashboard. https://covid19.who.int/. Updated on November 30, 2020. Accessed on November 30,2020 .

2. $X \cup Z$, Shi L, Wang $Y$, Zhang J, Huang L, Zhang $C$, et al. Pathological findings of COVID-19 associated with acute respiratory distress syndrome. Lancet Respir Med 2020; 8:420-2. [CrossRef]
3. Boban M. Novel corona virus disease (COVID-19) update on epidemiology, pathogenicity, clinical course and treatments. Int J Clin Pract 2021; 75: e13868. [CrossRef]

4. de Groot P, Munden RF. Lung cancer epidemiology, risk factors, and prevention. Radiol Clin North Am 2012; 50:863-76. [CrossRef]

5. Travis WD, Costabel U, Hansell DM, King TE Jr, Lynch DA, Nicholson AG, et al. An official American Thoracic Society/European Respiratory Society statement: Update of the international multidisciplinary classification of the idiopathic interstitial pneumonias. Am J Respir Crit Care Med 2013; 188:733-48. [CrossRef]

6. Kumar A, Cherian SV, Vassallo R, Yi ES, Ryu JH. Current concepts in pathogenesis, diagnosis, and management of smoking-related interstitial lung diseases. Chest 2018; 154:394-408. [CrossRef]

7. Strzelak A, Ratajczak A, Adamiec A, Feleszko W. Tobacco smoke induces and alters immune responses in the lung triggering inflammation, allergy, asthma and other lung diseases: a mechanistic review. Int J Environ Res Public Health 2018; 15:1033. [CrossRef]

8. Stämpfli MR, Anderson GP. How cigarette smoke skews immune responses to promote infection, lung disease and cancer. Nat Rev Immunol 2009; 9:377-84. [CrossRef]

9. Zong D, Liu X, Li J, Ouyang R, Chen P. The role of cigarette smoke-induced epigenetic alterations in inflammation. Epigenetics Chromatin 2019; 12:65. [CrossRef]

10. López-Hernández $Y$, Rivas-Santiago CE, López JA, Mendoza-Almanza G, Hernandez-Pando R. Tuberculosis and cigarette smoke exposure: An update of in vitro and in vivo studies. Exp Lung Res 2018; 44:113-26. [CrossRef]

11. Altet MN, Alcaide J, Plans P, Taberner JL, Saltó E, Folguera $\mathrm{LI}$, et al. Passive smoking and risk of pulmonary tuberculosis in children immediately following infection. A case-control study. Tuber Lung Dis 1996; 77:537-44. [CrossRef]

12. Donoghue M, Hsieh F, Baronas E, Godbout K, Gosselin $M$, Stagliano $N$, et al. A novel angiotensin-converting enzyme-related carboxypeptidase (ACE2) converts angiotensin I to angiotensin 1-9. Circ Res 2000; 87: E1-9. [CrossRef]

13. Dalan R, Bornstein SR, El-Armouche A, Rodionov RN, Markov A, Wielockx B, et al. The ACE-2 in COVID-19: Foe or Friend? Horm Metab Res 2020; 52:257-63. [CrossRef]

14. Leung JM, Yang CX, Tam A, Shaipanich T, Hackett $T L$, Singhera GK, et al. ACE-2 expression in the small airway 
epithelia of smokers and COPD patients: implications for COVID-19. Eur Respir J 2020; 55:2000688. [CrossRef]

15. Hatmal MM, Alshaer W, Al-Hatamleh MAl, Hatmal M, Smadi $O$, Taha MO, et al. Comprehensive structural and molecular comparison of spike proteins of SARS-CoV-2, SARS-CoV and MERS-CoV, and their interactions with ACE2. Cells 2020; 9: E2638. [CrossRef]

16. Wang $Q$, Zhang $Y, W_{u} L$, Niu S, Song C, Zhang Z, et al. Structural and functional basis of SARS-CoV-2 entry by using human ACE2. Cell 2020; 181:894-904.e9. [CrossRef]

17. National Institutes of Health, U.S.; Department of Health and Human Services. Novel Coronavirus Structure Reveals Targets for Vaccines and Treatments. 2020. Available online: www.nih.gov/news-events/nihresearchmatters /novel-coronavirus-structure-revealstargets-vaccines-treatments. Available on March 3, 2020. Accessed on December 11, 2020.

18. Wrapp D, Wang N, Corbett KS, Goldsmith JA, Hsieh CL, Abiona $O$, et al. Cryo-EM structure of the 2019-nCoV spike in the prefusion conformation. Science 2020; 367:1260-3. [CrossRef]

19. Hamming I, Timens W, Bulthuis ML, Lely AT, Navis G, van Goor H. Tissue distribution of ACE2 protein, the functional receptor for SARS coronavirus. A first step in understanding SARS pathogenesis. I Pathol 2004; 203:631-7. [CrossRef]

20. Cai, G. Bulk and Single-Cell Transcriptomics Identify Tobacco-Use Disparity in Lung Gene Expression of ACE2, the Receptor of 2019-nCov. Preprints 2020; 2020020051. [CrossRef]

21. Changeux JP, Amoura Z, Rey F, Miyara M. A nicotinic hypothesis for Covid-19 with preventive and therapeutic implications. C R Biol 2020; 343:33-9. [CrossRef]

22. Zhou $F, Y \cup T, D \cup R$, Fan G, Liu Y, Liu Z, et al. Clinical course and risk factors for mortality of adult inpatients with COVID-19 in Wuhan, China: a retrospective cohort study. Lancet 2020; 395:1054-62. [CrossRef]

23. Zhang JJ, Dong X, Cao YY, Yuan YD, Yang YB, Yan YQ, et al. Clinical characteristics of 140 patients infected with
SARS-CoV-2 in Wuhan, China. Allergy 2020; 75:173041. [CrossRef]

24. Huang $C$, Wang $Y$, Li $X$, Ren $L$, Zhao J, Hu Y, et al. Clinical features of patients infected with 2019 novel coronavirus in Wuhan, China. Lancet 2020; 395:497-506. [CrossRef]

25. Guan WJ, Ni ZY, Hu Y, Liang WH, Ou CQ, He JX, et al. Clinical characteristics of coronavirus disease 2019 in China. N Engl J Med 2020; 382:1708-20. [CrossRef]

26. Liu W, Tao ZW, Wang L, Yuan ML, Liu K, Zhou L, ef al. Analysis of factors associated with disease outcomes in hospitalized patients with 2019 novel coronavirus disease. Chin Med J (Engl) 2020; 133:1032-8. [CrossRef]

27. Yang $X, Y \cup Y, X \cup J$, Shu $H, X i a J$, Liu $H$, et al. Clinical course and outcomes of critically ill patients with SARSCoV-2 pneumonia in Wuhan, China: a single-centered, retrospective, observational study. Lancet Respir Med 2020; 8:475-81. [CrossRef]

28. Guan WJ, Liang WH, Zhao Y, Liang HR, Chen ZS, Li YM, et al. Comorbidity and its impact on 1590 patients with COVID-19 in China: a nationwide analysis. Eur Respir J 2020; 55:2000547. [CrossRef]

29. Wang R, Pan M, Zhang X, Han M, Fan X, Zhao F, et al. Epidemiological and clinical features of 125 Hospitalized Patients with COVID-19 in Fuyang, Anhui, China. Int J Infect Dis 2020; 95:421-8. [CrossRef]

30. Miyara M, Tubach F, Amoura Z. Low incidence of daily active tobacco smoking in patients with symptomatic COVID-19 infection. Qeios 2020. [CrossRef]

31. Zhao Q, Meng M, Kumar R, Wu Y, Huang J, Lian N, et al. The impact of COPD and smoking history on the severity of COVID-19: A systemic review and meta-analysis. J Med Virol 2020; 92:1915-21. [CrossRef]

32. Vardavas Cl, Nikitara K. COVID-19 and smoking: A systematic review of the evidence. Tob Induc Dis 2020; 18:20. [CrossRef]

33. Emami A, Javanmardi F, Pirbonyeh N, Akbari A. Prevalence of underlying diseases in hospitalized patients with COVID-19: a systematic review and meta-analysis. Arch Acad Emerg Med 2020; 8: e35. [CrossRef] 